\title{
PENGARUH MODAL INTELEKTUAL DAN UKURAN PERUSAHAAN TERHADAP PROFITABILITAS BANK UMUM SYARIAH (STUDI PADA BANK UMUM SYARIAH DI INDONESIA TAHUN 2013-2017)
}

\author{
Sarah Maqhfirah ${ }^{1}$, Wida Fadhlia*2 \\ ${ }^{1,2}$ Program Studi Akuntansi Fakultas Ekonomi dan Bisnis Universitas Syiah Kuala \\ e-mail: sarah.maqhfirah13@gmail.com ${ }^{1}$, widafadhlia@ unsyiah.ac.id ${ }^{2}$ \\ * Corresponding Author
}

\begin{abstract}
Abstrak
This study aims to (1) To determine the effect of intellectual capital on the profitability of Islamic commercial banks, (2) To determine the effect of company size on the profitability of Islamic commercial banks. (3) To determine the effect of intellectual capital and company size together on the profitability of a Sharia Commercial Bank. The population in this study were 14 Islamic commercial banks in Indonesia. The sampling technique in this study used purposive sampling technique. This study is a study that uses secondary data for research. Secondary data in the form of annual reports and financial reports obtained on the website of each Islamic commercial bank. The conclusions resulting from this study are (1) Intellectual capital affects the profitability of Islamic commercial banks, (2) Firm size influences the profitability of Islamic commercial banks, (3) Intellectual capital and company size together influence profitability.
\end{abstract}

Keywords: Profitability, Intellectual Capital, Firm Size

\section{Pendahuluan}

Perkembangan bank syariah di Indonesia mengalami perlambatan disebabkan pangsa pasar (market share) perbankan yang ada di negara Indonesia begitu kecil jika dibandingkan dengan beberapa negara yang mesyarakatnya mayoritas muslim. Perbankan syariah di Indonesia saat ini baru memiliki pangsa pasar 5,7 persen. Sementara di Arab Saudi sudah 51,1 persen dan Malaysia sebesar 23,8 persen (Republika.co.id, 8/12/2018). Kinerja keuangan merupakan sebuah analisis untuk mengetahui apakah sebuah entitas sudah mengerjakan peraturan dalam menjalankan keuangan dengan benar (Fahmi, 2012:2). Aspek kinerja keuangan yang akan diteliti pada penelitian ini hanya kinerja rasio profitabilitas yaitu ROA. Alasan pemilihan rasio profitabilitas karena profitabilitas adalah rasio yang sesuai untuk mengukur kinerja sebuah bank dibandingkan rasio lain (Sutojo 2004:55). Hal ini dikarenakan rasio profitabilitas mempunyai manfaat dan tujuan untuk pihak internal dan eksternal, paling utama pihak yang mempunyai keperluan dengan entitas.

Rasio profitabilitas adalah rasio dipakai untuk memberi nilai kepada suatu entitas dalam hal pencarian laba. Rasio profitabilitas akan memberi besarnya level efektivitas manajemen dalam sebuah entitas (Kasmir, 2014:115). ROA (Return on Asset) merupakan rasio yang dipakai memproaksi kinerja keuangan.

Salah satu tantangan terbesar yang sering dialami oleh perbankan syariah adalah kurangnya SDM yang berkualitas sehingga menjadi masalah terbesar dalam meningkatkan potensi yang ada dan hal tersebut juga menjadi penyebab terhambatnya perkembangan industri keuangan syariah. (Kompas.com, 08/07/2018).

Menurut Ulum (2007), Modal Intelektual adalah hal penting, dikarenakan bisa berpengaruh pada kinerja keuangan sebuah entitas. SDM adalah unsur yang penting untuk meningkatkan kinerja keuangan pada suatu perusahaan (Widjanarko, 2006). Dalam Penelitian ini Modal intelektual diukur dengan model Pullic (1998) yaitu

(Value Added Intellectual Coefficient).

Ukuran perusahaan juga menjadi unsur penting yang berpengaruh terhadap kinerja perbankan. Ukuran perusahaan adalah sebuah skala 
untuk menilai besar atau kecilnya sebuah entitas apakah suatu perusahaan termasuk dalam perusahaan kecil, sedang, atau besar. Riyanto (2008:313) menyatakan "ukuran perusahaan dapat dilihat dari besarnya nilai aktiva, nilai equity, dan nilai penjualan". Ukuran perusahaan bisa dihitung menggunakan total aktiva dari perusahaan saat akhir periode. Penelitian berikut mengukur ukuran suatu perusahaan menggunakan total asset, dikarenakan total aktiva representatif dan stabil dibandingkan dengan penjualan yang dapat dipengaruhi oleh penawaran dan permintaan.

Penelitian yang dilakukan oleh Faradina (2017) meneliti pengaruh modal intelektual terhadap kinerja keuangan dengan hasil modal intelektual mempunyai pengaruh terhadahap kinerja keuangan. Penelitian Lestari et al., (2016), Dewanata et al., (2016), Maisaroh (2015), Khasanah (2016) menunjukkan modal intelektual bepengaruh terhadap kinerja keuangan.

Hasil berbeda diperlihatkan oleh penelitian Kuryanto dan Syafruddin (2008), Firer dan William (2003) menyatakan modal intelektual tidak mempunyai pengaruh pada kinerja keuangan. Mohiuddin et al., (2008) juga menemukan hasil bahwa modal intelektual tidak mempunyai pengaruh terhadap kinerja keuangan.

Hasil Arini (2009), serta penelitian Sartika (2012), Rahmawati dan Tjahyadi (2017), Akbar (2013), Hesti (2010), Tisna dan Agustami (2016) mengungkapkan jika ukuran suatu perusahaan mempunyai pengaruh pterhadap kinerja keuangan. Namun mempunyai perbedaan dengan penelitian dari Hidayat et al., (2015), Setiawan (2009), Ali \& Ghazali (2018) dengan hasil ukuran perusahaan tidak pengaruh pada kinerja keuangan, dikarenakan semakin besar suatu ukuran entitas selanjutnya biaya yang dikeluarkan oleh entitas semakin banyak.

Berdasarkan penjelasan latar belakang tersebut maka penulis tertarik untuk melakukan penelitian dengan judul "Pengaruh Modal Intelektual dan Ukuran Perusahaan Terhadap Profitabilitas Bank Umum Syariah (Studi Pada Bank Umum Syariah di Indonesia Tahun 2013-2017)".

Berdasarkan latar belakang yang telah dipaparkan sebelumnya, permasalahan yang timbul dalam penelitian ini dirumuskan sebagai berikut:

1) Apakah modal intelektual berpengaruh terhadap profitabilitas BUS?

2) Apakah ukuran perusahaan berpengaruh terhadap profitabilitas BUS?

3) Apakah modal intelektual dan ukuran perusahaan secara bersama-sama berpengaruh terhadap profitabilitas BUS?

Tujuan penelitian ini adalah seperti berikut:

1) Untuk melihat pengaruh modal intelektual terhadap profitabilitas Bank Umum Syariah.

2) Untuk melihat pengaruh ukuran perusahaan terhadap profitabilitas BUS.

3) Untuk melihat pengaruh modal intelektual dan ukuran perusahaan secara bersama-sama terhadap profitabilitas BUS.

\section{Kajian Pustaka}

Teori yang Mendasari Penelitian

Dasar dilakukannya penelitian adalah sebagai berikut.

\section{Stakeholder Theory}

Menurut Ulum (2009:42) Stakeholder adalah Individu atau kelompok yang bisa diidentifikasi dan bisa mempengaruhi pencapaian tujuan suatu organisasi. Rivai dan Sagala (2010:86) menyatakan bahwa stakeholder dalam suatu perusahaan sangat penting dan perusahaan harus mengetahui mana saja stakeholder yang terlibat dalam suatu perusahaan. Maka perusahaan akan bisa memberikan pelayanan secara cepat dan dapat memenuhi keinginan stakeholder.

\section{Resource Based Theory}

Resource Based Theory atau teori SDM dalam menganalisis kemampuan bersaing menggunakan pendekatan berbasis sumber daya. Menurut Suhendah (2012) "teori ini menjelaskan tiga sumber daya, pertama sumber daya manusia yang terdiri dari pengetahuan dimiliki karyawan dan pengalaman, kedua sumber daya dari organisasional yang terdiri dari sistem perencanaan, struktur, pengendalian, pengawasan, dan pengendalian sosial organisasi dengan lingkungan eksternal, ketiga sumber daya berwujud teridiri dari technology, peralatan, pabrik, dan lokasi”.

\section{Pengertian Bank Syariah}

Muhammad (2005:13) menyatakan bahwa 
perbankan syariah merupakan perbankan yang melakukan aktivitas tanpa adanya unsur riba. Bank syariah juga adalah perbankan yang operasinya tidak mengenal sistem bunga. Menurut Ascarya (2008:3), perbankan syariah adalah entitas berbentuk keuangan yang mempunyai manfaat untuk kelancaran perekonomian dalam sektor riil dengan cara (jual beli, investasi dan lainnya) yang berlandaskan pada prinsip syari'ah, yaitu tidak boleh melakukan kegiatan yang melenceng dari nilai syari'ah baik yang bersifat mikro maupun makro.

\section{Profitabilitas Bank Syariah}

Rasio yang dipakai untuk menghitung kinerja keuangan bank adalah sebagai berikut: Profitabilitas, Likuiditas, Struktur Modal, Aktiva Produktif, Efisiensi, dan Resiko Usaha (Siamat, 1996:67). Namun penelitian berikut hanya memakai rasio dari profitabilitas yaitu ROA karena menurut Sutojo (2004:55) profitabilitas adalah rasio yang sesuai untuk menghitung kinerja sebuah perbankan dibandingkan dengan rasio lainnya. Hal ini dikarenakan rasio profitabilitas mempunyai manfaat dan tujuan untuk pihak internal dan eksternal, yang paling utama adalah pihak yang mempunyai keperluan dengan suatu perusahaan.

\section{Modal Intelektual \\ Definisi Modal Intelektual}

Definisi modal intelektual masih sering dimaknai berbeda-beda. Sebagai suatu konsep, modal intelektual memiliki keterkaitan dengan knowledge manusia dan teknologi yang dipakai serta merupakan modal tidak berwujud (intangible assets). Menurut Ulum (2009:20), modal intelektual merupakan material yang disusun, dan dipakai untuk dapat menghasilkan nilai aset yang tinggi.

Menurut (Bontis 2000, Sveiby 1998, dan Saint-Onge 1996, Pulic 2000), modal intelektual terdiri dari 3 komponen yaitu:

1) Human Capital (Modal Manusia)

Suhendah (2012) menyatakan bahwa Human Capital (HC) adalah komponen terpenting dari IC yang merupakan sumber perbaikan (improvement) dan inovasi, human capital adalah bagian yang susah untuk dapat diukur. Pengetahuan, kompetensi, dan keterampilan merupakan sumber dari HC. Human capital bisa naik apabila entitas bisa memanfaatkan pengetahuan karyawannya.

2) Struktural Capital (Modal Struktural)

Menurut Bontis et al., (2000) Structural capital (SC) adalah sebuah alat yang membantu pegawai agar mencapai kinerja optimal, terdiri dari hardware, database, software, struktur organisasi, trademark, patent, keahlian perusahaan menjangkau pasar, dan keahlian perusahaan dalam mendukung produktivitas pegawai, jika produktivitas pegawai dapat naik maka juga akan meningkatkan kinerja dalam suatu entitas.

3) Capital Employed

Menurut Arifah dan Medyawati (2012), Capital Employed adalah sebuah hubungan baik perusahaan dengan pelanggan, baik dari hubungan perusahaan dengan masyarakat maupun dengan pemerintah, bersumber dari supplayer yang kompeten, dan dari konsumen yang puas maupun loyal pada pelayanan entitas.

\section{Pengukuran Modal Intelektual}

Pengukuran IC merupakan hal yang begitu penting untuk dilakukan dengan adanya peran dari modal intelektual saat ini. Modal intelektual dihitung dengan menggunakan model Pullic (1998) yaitu (Value Added Intellectual Coefficient).

Langkah pertama adalah melihat keahlian perusahaan dalam penciptaan nilai. Untuk dapat menilai keberhasilan suatu bisnis VA merupakan indikator yang paling objektif (Pullic, 1998). VA dapat dihitung dengan cara mengurangi output dengan input.

Menurut Pulic (1998), modal intelektual terdiri dari 3 (tiga) komponen utama dari VAIC (Value Added Capital Employed) yang digunakan untuk mengukur modal intelektual, berupa CEE (Capital employed Eficiency), HCE (Human Capital Eficiency), dan SCE (Structural Capital Efficiency).

\section{Ukuran Perusahaan}

Menurut Riyanto (2008:313) ukuran perusahaan merupakan ukuran besar kecilnya suatu perusahaan yang bisa dilihat dari besarnya nilai aktiva, nilai penjualan, dan nilai equity". Berdasarkan UU No. 20 Tahun 2008 tentang ukuran perusahaan terbagi 
menjadi 4 kategori yang terdiri dari usaha mikro, usaha kecil, usaha menengah, dan usaha besar". Untuk mengklasifikasikan ukuran suatu perusahaan tersebut diukur dari total aktiva maupun total dari penjualan suatu entitas.

Sartono (2011:249) mengatakan perusahaan yang besar mempunyai kemudahan dalam mendapatkan modal dibandingkan perusahaan yang masih kecil. dikarenakan adanya kemudahan entitas yang besar akan mempunyai fleksibilitas yang tinggi dibandingkan dengan perusahaan kecil.

Untuk menentukan ukuran dari suatu perusahaan digunakan keseluruhan aset. Ukuran aktiva akan dihitung menggunakan Ln dari total aktiva . Munawir (2010:30) menyatakan rumus untuk mengukur ukuran perusahaan sebagai berikut:

$$
\text { Size }=\text { Ln Total Asset }
$$

Keterangan: $\mathrm{Ln}=$ Logaritma Natural

\section{Penelitian Terdahulu}

Hasil studi yang sudah diteliti oleh peneliti terdahulu yang akan dijelaskan berikut ini:

Khasanah (2016) yang meneliti pengaruh intellectual capital dan IPI (islamicity performance index) terhadap kinerja keuangan perbankan syariah di Indonesia. Hasil penelitian memperlihatkan modal intelektual yang diukur memakai dan IPI berpengaruh terhadap kinerja keuangan.

Ousama \& Fatima (2015) meneliti pengaruh dari modal intelektual terhadap kinerja keuangan perbankan syariah di Malaysia. Hasil penelitian memperlihatkan modal intelektual komponennya mempunyai pengaruh terhadap kinerja keuangan perbankan syariah di malaysia.

Lestari et al., (2016) Pengaruh Intellectual Capital pada Kinerja Keuangan bank syariah di Indonesia. Hasil memperlihatkan modal intelektual mempunyai pengaruh terhadap kinerja keuangan. Maisaroh (2015) melakukan penelitian yang menguji pengaruh IC (Intellectual Capital) dan IP (Islamicity Performance Index) terhadap profitability perbankan syariah. Hasil memperlihatkan modal intelektual dan islamicity index memiliki pengaruh pada profitabilitas BUS.

Rahmawati \& Tjahyadi (2017) melakukan penelitian yang menguji pengaruh ukuran perusahaan terhadap kinerja keuangan perbankan syariah. Hasil memperlihatkan ukuran perusahaan memiliki pengaruh terhadap kinerja keuangan perbankan syariah.

Berbeda dengan Atif ali \& Ghazali (2018) yang meneliti pengaruh ukuran perusahaan terhadap profitabilitas. Penelitian dilakukan di perbankan

syariah dan perbankan konvensional di pakistan. Hasil memperlihatkan ukuran perusahaan mempunyai pengaruh terhadap profitabilitas bank konvensional, akan tetapi ukuran perusahaan tidak berpengaruh terhadap profitabilitas perbankan syariah di pakistan.

\section{Kerangka Pemikiran}

\section{Pengaruh Modal Intelektual Terhadap Profitabilitas Bank Umum Syariah}

Perusahaan yang bisa mengolah sumber daya yang dimiliki secara bagus maka mempunyai potensi yang bagus dibandingkan entitas lain. Sumber daya manusia yang terampil dan kompeten merupakan suatu keunggulan yang dimiliki perusahaan.

Perusahaan yang bisa mengolah sumber daya intelektual dengan baik, selanjutnya akan mampu meningkatkan kemampuan pegawai di perusahaan tersebut. Jika produktivitas dalam suatu perusahaan meningkat maka akan diikuti oleh meningkatnya profitabilitas. Selain itu apabila karyawan dalam suatu perusahaan mendapat gaji dan tunjangan yang tinggi maka kinerja karyawan tersebut akan bagus dan maksimal sehingga hal tersebut dapat meningkatkan profitabilitas perusahaan tersebut. Pendapat tersebut sesuai dengan penelitian Khasanah (2016), Ousama \& Fatima (2015), Faradina (2017), Dewanata (2016), dan Maisaroh (2015) menyatakan modal intelektual mempunyai pengaruh terhadap pofitabilitas.

Berbeda didapatkan oleh Kuryanto dan Syafruddin (2008), Firer dan William (2003) dengan hasil IC tidak mempunyai pengaruh terhadap profitabilitas. Mohiuddin et al., (2008) menemukan hasil yaitu modal intelektual tidak memiliki pengaruh terhadap profitabilitas.

\section{Pengaruh Ukuran Perusahaan Terhadap Profitabilitas Bank Umum Syariah}

Menurut Riyanto (2008:313), "ukuran perusahaan merupakan ukuran besar kecilnya suatu perusahaan yang bisa dilihat dari besarnya nilai aktiva, nilai penjualan, dan nilai equity". Agus 
(2011:249) mengatakan perusahaan yang besar mempunyai kemudahan dalam mendapatkan modal dibandingkan dengan entitas yang masih kecil. dikarenakan adanya kelancaran tersebut perusahaan skala besar akan memiliki fleksibilitas yang tinggi.

Perusahaan yang mempunyai aset yang banyak biasanya mendeskripsikan kemapanan dalam perusahaan, jika total aset semakin besar maka modal yang diinvestasikan dan ukuran perusahaan akan ikut besar, hal tersebut akan membuat uang dalam perusahaan akan berputar semakin banyak dan kemudian akan meningkatkan kinerja perusahaan tersebut. Hal itu sejalan dengan hasil penelitian oleh Rahmawati \& Tjahyadi (2017), Arini (2009), Dewi (2012), Akbar (2013), Hesti (2010), Tisna dan Agustami (2016) yang mengatakan ukuran perusahaan memiliki pengaruh pada profitabilitas perbankan syariah.

Berbeda Hidayat (2015), Setiawan (2009), Ali \& Ghazali (2018) ukuran perusahaan tidak memiliki pengaruh pada profitabilitas, dikarenakan ukuran entitas yang besar akan banyak beban untuk perusahaan.

Berdasarkan penjelasan sebelumnya bisa dilihat pada Gambar 2.1 skema kerangka pemikiran.

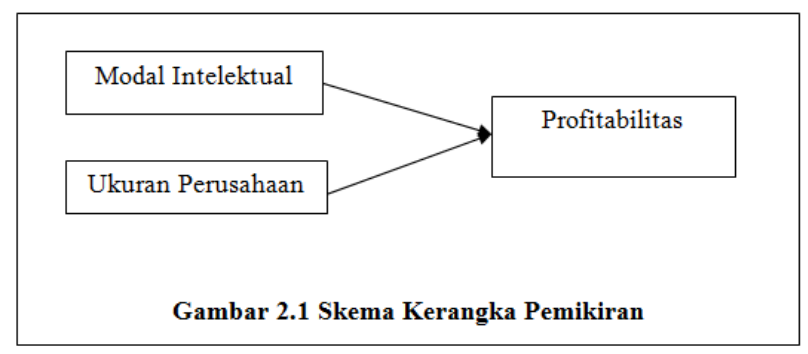

\section{Perumusan Hipotesis}

Dari penjelasan sebelumnya, maka hipotesis seperti berikut:

1) Modal intelektual berpengaruh terhadap profitabilitas Bank Umum Syariah tahun 2013- 2017.

2) Ukuran perusahaan berpengaruh terhadap profitabilitas Bank Umum Syariah tahun 2013- 2017.

3) Secara bersama-sama modal intelektual dan ukuran perusahaan berpengaruh terhadap profitabilitas Bank Umum Syariah tahun 20132017.

\section{Metode Penelitian \\ Desain Penelitian}

terdapat 6 (enam) hal dalam desain sebuah penelitian, yaitu:

1) Sifat Studi

Berdasarkan tujuan penelitian, maka uji hipotesis merupakan jenis penelitian yang dipakai. Untuk menguji pengaruh dari modal intelektual dan ukuran perusahaan terhadap profitabilitas BUS tahun 2013-2017.

2) Jenis Penelitian

Jenis penelitian yang dipakai adalah sebuah penelitian kausalitas, yaitu untuk melihat keterkaitan dari variabel, untuk menguji pengaruh satu variabel terhadap variabel yang lain.

3) Tingkat Intervensi Peneliti terhadap Studi

Penelitian berikut menggunakan intervensi minimal. Yaitu peneliti mendapatkan data dari BUS dan tidak mengintervensi kegiatan yang ada dalam bank umum syariah tersebut.

4) Situasi Studi

Apabila dilihat keterlibatan peneliti maupun kondisi lingkungan, penelitian ini dibuat dalam kondisi bebas aturan.

5) Unit Analisis

Semua BUS di indonesia tahun 2013-2017. Data didapatkan dari laporan tahunan maupun laporan keuangan bank umum syariah yang ada di Bursa Efek Indonesia (BEI) dari tahun 2013-2017.

6) Horizon Waktu

Dilihat dari horizon waktu, penelitian ini menggunakan horizon waktu studi analisis longitudinal dengan menggunakan data panel atau pooled data.

\section{Populasi dan Sampel Penelitian}

Populasi yang dipakai adalah semua BUS di indonesia tahun 2013-2017. Sampel dipilih menurut purposive sampling method, krarakteristik dipakai untuk menentukan sample seperti berikut:
1. Perbankan
Umum
Syariah
yang

melaporkan laporan tahunan maupun laporan keuangan berturut dari tahun 2013 sampai 2017.

\section{Sumber dan Teknik Pengumpulan Data}

Digunakan adalah data sekunder. Data sekunder yang dipakai adalah laporan keuangan. Laporan keuangan bersumber dari website BUS 
tahun 2013-2017.

\section{Operasionalisasi Variabel}

Dilakukan untuk menganalisis pengaruh modal intelektual dan ukuran perusahaan terhadap profitabilitas BUS tahun 2013-2017. Oleh sebab itu, harus dibuat uji mengenai hipotesis yang dikemukakan oleh peneliti. Mengacu pada kerangka pemikiran, definisi operasionalisasi mengenai variabel yang ada adalah sebagai berikut:

\section{Variabel Terikat (Dependen Variable) $(\mathbf{Y})$}

Variabel terikat yang dipakai adalah profitabilitas yang diukur dengan ROA. Rasio profitabilitas adalah rasio yang digunakan untuk mengukur keberhasilan sebuah entitas dalam mendapatkan laba. Rasio profitabilitas juga memberikan ukuran tingkat efektivitas manajemen dalam suatu perusahaan (Kasmir, 2014:115). Lestari dan Sugiharto (2007) menyatakan bahwa ROA merupakan rasio yang dipakai untuk menghitung laba bersih yang didapatkan dari pemakaian aset. Dengan begitu bisa dikatakan apabila ROA dalam sebuah entitas semakin naik maka produktivitas aset dalam menciptakan laba semakin baik. Hal ini membuat daya tarik entitas akan naik, karena hal tersebut perusahaan akan dilihat investor dan tingkat dividen akan terus tinggi. Khasanah (2016), Ousama \& Fatima (2015), Lestari et al., (2016), dan Rahmawati \& Tjahyadi (2017) mengukur kinerja keuangan menggunakan rumus seperti berikut:

$$
\text { Retum On Asset }=\frac{\text { Laba Bersih setelah pajak }}{\text { Total Aset }} \times 100 \%
$$

\section{Variabel Bebas (Independen Variable) (X)}

Menurut Sekaran dan Bougie (2011:72), "Variabel bebas adalah variabel yang berpengaruh pada variabel terikat. Variabel bebas yang digunakan adalah modal intelektual dan ukuran perusahaan".

\section{Modal intelektual}

Modal intelektual adalah metode VAIC (value added intellectual coefficient) yang dibuat pullic pada tahun 1998 untuk memberikan laporan mengenai efesiensi pembuatan nilai dari sebuah asset non fisik (intangible asset) dan aset yang fisik yang dipunyai sebuah entitas. VAIC adalah sebuah elemen pengukuran untuk sebuah kinerja modal intelektual perusahaan. Penelitian ini mengukur modal intelektual dengan memakai model pulic (1997) VAIC (value added intellectual capital). VAIC adalah gabungan tiga indikator value added yaitu seperti berikut:

1. Tahap pertama dilakukan dengan menghitung VA (Value Added). VA dihitungan dengan cara seperti berikut:

\section{$\mathrm{VA}=$ OUT-IN}

Keterangan:

OUT $($ output $)=$ Total dari Pendapatan .

IN (input) = Beban penjualan dan biaya lain-lain (kecuali beban tenaga kerja/karyawan).

2. Tahap kedua dengan cara menghitung CEE. Modal yang dipergunakan (Capital Employed/CE) diartikan total dari modal yang bisa digunakan pada intangible asset maupun tangible asset sebuah entitas (Pulic, 1998, Firer dan Williams, 2003). Dihitung dengan Capital Employed Efficiency (CEE) yaitu indikator efisiensi dari nilai tambah (Value Added) modal yang dipakai. Rumus untuk menghitung CEE yaitu:

$$
\mathrm{CEE}=\frac{\mathrm{VA}}{\mathrm{CE}}
$$

Keterangan:

CEE =Rasio dari VA terhadap CE.

VA $($ Value Added $)=$ Selisih antara output dan input. CE (Capital Employed $)=$ Total Aset.

3. Tahap ketiga dilakukan dengan cara menghitung HCE. Modal manusia (Human Capital/HC) bersumber pada nilai kolektif dari modal intelektual perusahaan yaitu pengetahuan, kompetensi dan keterampilan (Pulic, 1998, Firer dan Williams, 2003). Diukur dengan Human Capital Efisiensi (HCE) yaitu indikator efisiensi nilai tambah (Value Added) modal manusia. Rumus untuk menghitung HCE yaitu: 


\section{$\mathrm{HCE}=\frac{\mathrm{VA}}{\mathrm{HC}}$}

Keterangan:

HCE $=$ Rasio dari VA terhadap HC.

VA $($ value added $)=$ Selisih antara output dan input. HC (human capital) = Beban Karywan.

4. Tahap keempat dilakukan dengan cara menghitung SCE. Modal struktural (Structural Capital/SC) bisa diartikan sebagai formula, sistem informasi, competitive intelligence, Trademark, kebijakan, dan sebagainya, hasil dari sebuah produk maupun sistem dari suatu entitas yang dibuat dari periode ke periode (Pulic, 1998; Firer dan Williams, 2003). Diukur dengan Structural Capital Efficiency (SCE) yaitu indikator efisiensi nilai tambah (Value Added) modal struktural.Rumus untuk menghitung SCE yaitu:

$$
\mathrm{SCE}=\frac{\mathrm{SC}}{\mathrm{VA}_{\mathrm{A}}}
$$

Keterangan:

$\mathrm{SCE}=$ Rasio SC terhadap VA.

$\mathrm{SC}($ struktural capital $)=\mathrm{VA}-\mathrm{HC} . \mathrm{VA}=$ Value

Added.

5. Tahap kelima menghitung VAIC (Value Added Intellectual Capital). VAIC memperlihatkan kemampuaan intelektual suatu organisasi, VAIC adalah hasil dari perhitungan dari tiga indikator sebelumnya.

$$
\mathrm{VAIC}^{\mathrm{TM}}=\mathrm{CEE}+\mathrm{HCE}+\mathrm{SCE}
$$

\section{Ukuran Perusahaan}

Menurut Riyanto (2008:313) "ukuran perusahaan merupakan ukuran besar kecilnya suatu perusahaan yang bisa dilihat dari besarnya nilai aktiva, nilai penjualan, dan nilai equity". Berdasarkan UU No. 20 Tahun 2008 tentang ukuran perusahaan terbagi menjadi 4 kategori yang terdiri dari usaha mikro, usaha kecil, usaha menengah, dan usaha besar". Untuk mengklasifikasikan ukuran suatu perusahaan tersebut diukur dari total aktiva maupun total dari penjualan suatu entitas.

Sartono (2011:249) mengatakan perusahaan yang besar mempunyai kemudahan dalam mendapatkan modal dibandingkan perusahaan yang masih kecil. dikarenakan adanya kemudahan entitas yang besar akan mempunyai fleksibilitas yang bagus.

Untuk menentukan ukuran dari suatu perusahaan digunakan keseluruhan aset. Ukuran aktiva akan dihitung menggunakan Ln dari total aktiva . Munawir (2010:30) menyatakan rumus untuk mengukur ukuran perusahaan sebagai berikut: Size $=$ Ln Total Asset

Keterangan: $\mathrm{Ln}=$ Logaritma Natural

\section{Hasil Penelitian \\ Deskripsi Objek Penelitian}

Penelitian ini memakai panel data, yaitu penelitian hanya dirangkum atau disusun dalam suatu periode observasi dan mempunyai hasil pengamatan yang sejenis pada setiap periode. Menurut data yang didapatkan dari web www.idx.com, populasi adalah 14 BUS yang ada di Indonesia. Dari kriteria yang ada, didapatkan sampel sebanyak 10 BUS yang dipakai dalam 5 tahun, maka jumlah sampel dalam penelitian menjadi 50 data pengamatan.

\section{Statistik Deskriptif}

Tabel 4.1
Deskriptif Data Penelitian
Descriptive Statistics
\begin{tabular}{|l|r|r|r|r|r|}
\hline & N & Minimum & Maximum & \multicolumn{1}{c|}{ Mean } & Std. Deviation \\
\hline ROA & 50 & -2013 & .0550 & .006440 & .0060103 \\
Modal Intelektual & 50 & -3.7915 & 9.5086 & 2.5748230 & 2.2178488 \\
Size & 50 & 14.06 & 18.29 & 16.0734 & 1.32026 \\
Valid N (listwise) & 50 & & & & \\
\hline
\end{tabular}

Sumber: Output SPSS 20 (2019)

Nilai terendah dari profitabilitas dalam hal ini ROA sebagai variabel dependen adalah $-0,2013$ artinya adalah bahwa ROA hanya sebesar $-0,2013$, yang dialami oleh maybank syariah tahun 2015. Nilai tertinggi dari ROA adalah 0,0550 dialami oleh Maybank Syariah tahun 2017. Nilai rata-rata ROA sebesar 0,006440. Nilai standar deviasi sebesar 0,0060103 lebih rendah dari nilai rataratanya, hal ini memiliki makna bahwa secara umum perusahaan perbankan syariah yang menjadi populasi dalam penelitian ini memiliki ROA sebesar 0,00644 .

Variabel independen yang pertama adalah modal intelektual. Modal intelektual dengan nilai terendah adalah $-3,7915$ yaitu pada bank victoria syariah pada tahun 2017. Modal intelektual tertinggi 
adalah 9,5086 yaitu pada Bank Syariah Bukopin pada tahun 2015. Nilai rata-rata modal intelektual adalah sebesar 2,574823. Nilai standar deviasi sebesar 2,2178488, hal ini memiliki makna bahwa secara umum perusahaan perbankan syariah yang menjadi populasi dalam penelitian ini memiliki modal intelektual sebesar 2,574823.

Variabel independen yang kedua adalah ukuran perusahaan. Variabel ukuran perusahaan dengan nilai terendah adalah 14,059 yaitu pada Maybank Syariah Indonesia di tahun 2017. Ukuran perusahaan tertinggi adalah 18,2922 Bank Syariah Mandiri di tahun 2017. Nilai rata-rata ukuran perusahaan adalah sebesar 16,0734. Nilai standar deviasi sebesar 1,32026 hal ini memiliki makna bahwa secara umum perusahaan perbankan syariah yang menjadi populasi dalam penelitian ini memiliki ukuran perusahaan sebesar 16,0734.

\section{Uji Asumsi Klasik}

\section{Uji Normalitas}

Tabel 4.2

Uji Normalitas (Kolmogrov-Smirnov Test)

One-Sample Kolmogorov-Smirnov Test

\begin{tabular}{|ll|r|}
\hline & & $\begin{array}{r}\text { Unstandardiz } \\
\text { ed Residual }\end{array}$ \\
\hline $\mathrm{N}$ & & 50 \\
Normal Parameters a,b & Mean & .0000000 \\
& Std. Deviation & .53300040 \\
Most Extreme & Absolute & .161 \\
Differences & Positive & .115 \\
& Negative & -.161 \\
Kolmogorov-Smirnov Z & & 1.135 \\
Asymp. Sig. (2-tailed) & & .152 \\
\hline
\end{tabular}

a. Test distribution is Normal.

b. Calculated from data.

Dari Tabel 4.2 memperlihatkan nilai terdistribusi normal dikarenakan nilai dari Asymp. Sig. (2-tailed) 0,152 > 0,05 (Ghozali, 2009:114). Dapat ditarik kesimpulan bahwa pola terdistribusi dan model dalam regresi melengkapi uji ini dan bisa digunakan untuk menguji statistik lainnya.

\section{Uji Multikolonieritas}

Tabel 4.3

Hasil Uji Multikolonieritas

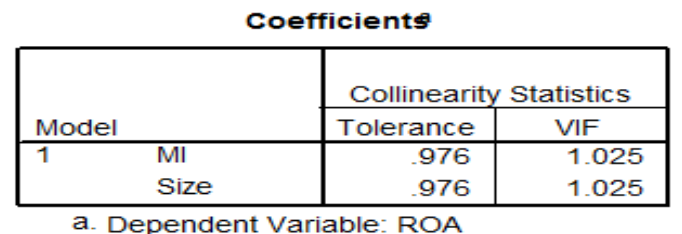

Dari hasil tes dari tabel 4.3 terlihat nilai toleran untuk seluruh variabel bebas lebih besar dari 0,10, dan VIF kurang dari 10 memperlihatkan tidak ada multikolinieritas antara variabel independen.

\section{Uji Heteroskedastisitas}

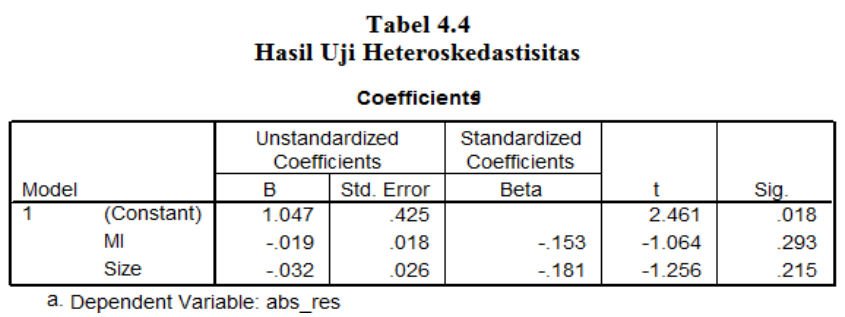

Dari hasil pengujian Tabel 4.4 bisa dilihat modal intelektual dan ukuran perusahaan mempunyai nilai signifikans $>0,05$. Memperlihatkan bahwa uji glejser yang dipakai terbebas dari adanya heteroskedastisitas.

\section{Uji Autokorelasi}

Tabel 4.5

Hasil Uji Autokorelasi

Model Summary

\begin{tabular}{|l|r|r|r|r|r|}
\hline Model & R & R Square & $\begin{array}{c}\text { Adjusted } \\
\text { R Square }\end{array}$ & $\begin{array}{c}\text { Std. Error of } \\
\text { the Estimate }\end{array}$ & $\begin{array}{c}\text { Durbin- } \\
\text { Watson }\end{array}$ \\
\hline 1 & $.429^{\mathrm{a}}$ & .184 & .149 & .54422 & 2.294 \\
\hline
\end{tabular}

b. Dependent Variable: ROA

Hasil dari Tabel 4.4 memperlihatkan pada sig $5 \%$ variabel terikat nilai $\mathrm{dw}$ 2,294 dengan nilai $\mathrm{du}=1,628 \quad$ dan nilai $\quad 4-\mathrm{du}=2,372$ $(1,628<2,294<2,372) \quad$ menunjukkan tidak ada autokorelasi.

\section{Pengujian Hipotesis}

Hasil Pengujian Hipotesis Hasil Regresi Linier Berganda 
Tabel 4.6

Hasil Regresi Linear Berganda

Coefficients $^{\mathrm{a}}$

\begin{tabular}{|ll|r|r|r|r|r|}
\hline \multirow{2}{*}{ Model } & \multicolumn{2}{|c|}{$\begin{array}{c}\text { Unstandardized } \\
\text { Coefficients }\end{array}$} & \multicolumn{2}{c|}{$\begin{array}{c}\text { Standardized } \\
\text { Coefficients }\end{array}$} & & \multirow{2}{*}{} \\
\cline { 2 - 5 } & \multicolumn{1}{|c|}{$\mathrm{B}$} & Std. Error & \multicolumn{1}{|c|}{ Beta } & \multicolumn{1}{c|}{$\mathrm{t}$} & \multicolumn{1}{c}{ Sig. } \\
\hline 1 & (Constant) & -2.161 & .987 & & -2.190 & .034 \\
& Ml & .094 & .042 & .297 & 2.229 & .031 \\
& Size & .160 & .060 & .358 & 2.687 & .010 \\
\hline
\end{tabular}

a. Dependent Variable: ROA

Persamaan regresi pengukuran profitabilitas yang diproksikan dengan ROA yang didapatkan dari hasil penghitungan statistik seperti pada Tabel 4.5 adalah:

$$
Y=-2,161+0,094+0,160+e
$$

Dari persamaan regresi di atas bisa dilihat bahwa:

1) Konstanta (a) -2,161. Berarti, jika modal intelektual dan ukuran perusahaan dianggap konstan, maka besar ROA BUS pada tahun 2013-2017 sebesar 2,161\%.

2) Koefisien regresi dari modal intelektual 0,094 . Artinya kenaikan satu modal intelektual dengan berasumsi variabel lain tetap akan menaikkan ROA BUS pada tahun 2013-2017 sebesar 0,094.

3) Koefisien regresi ukuran perusahaan 0,160 . Artinya setiap kenaikan dari ukuran perusahaan dengan berasumsi variabel lainnya tetap menaikkan ROA BUS pada tahun 20132017 sebesar 0,160 .

\section{Uji Signifikansi Bersama-sama (Uji Statistik F)}

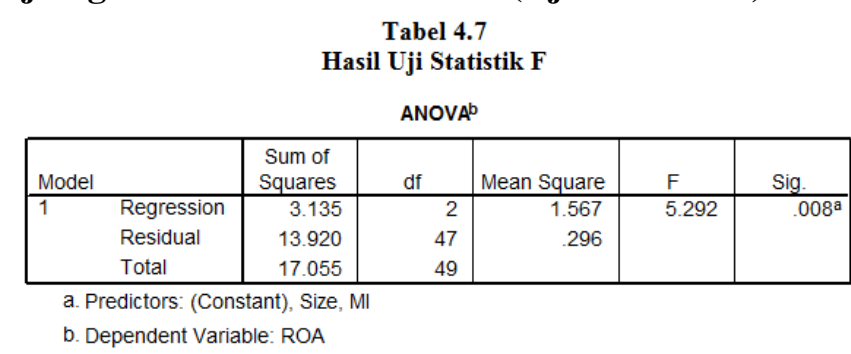

Dari tabel 4.6, signifikansi hasil pengujian variabel bebas (X1 dan X2) dapat mempengaruhi variabel terikat. Dari uji F 5,292 dan nilai 0,008 berarti bahwa variabel modal intelektual dan ukuran perusahaan secara bersama-sama dapat mempengaruhi ROA. Selanjutnya, hipotesis ketiga yang mengatakan bahwa modal intelektual dan ukuran perusahaan bersama-sama memengaruhi ROA diterima.

\section{Uji Signifikansi Parsial (Uji t)}

Tabel 4.8

Hasil Uji Statistik t

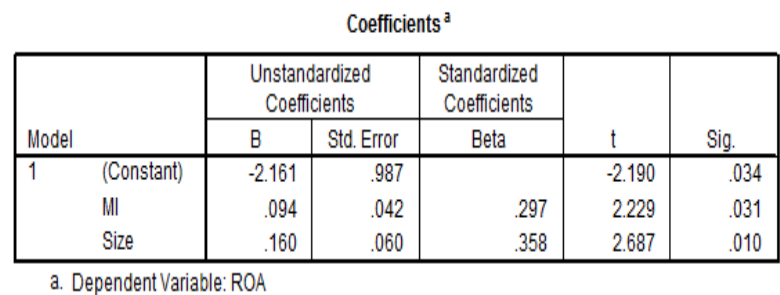

Dari pengujian pada Tabel 4.8 dapat dilihat seperti berikut:

1. modal intelektual (mempunyai signifikansi 0,031 lebih rendah dari 0,05 (5\%). Memperlihatkan modal intelektual berpengaruh terhadap ROA. Hipotesis pertama modal intelektual berpengaruh terhadap profitabilitas bisa diterima.

2. ukuran perusahaan (mempunyai signifikans 0,010 lebih rendah dari 0,05 (5\%). Memperlihatkan ukuran perusahaan berpengaruh terhadap ROA. Hipoteisis kedua ukuran perusahaan memengaruhi profitabilitas dapat diterima.

\section{Koefisien Determinasi}

Tabel 4.9

Hasil Uji Koefisien Determinasi

Model Summary
\begin{tabular}{|l|c|r|r|r|c|}
\hline Model & R & R Square & $\begin{array}{c}\text { Adjusted } \\
\text { R Square }\end{array}$ & $\begin{array}{c}\text { Std. Error of } \\
\text { the Estimate }\end{array}$ & $\begin{array}{c}\text { Durbin- } \\
\text { Watson }\end{array}$ \\
\hline 1 & $.429^{\mathrm{a}}$ & .184 & .149 & .54422 & 2.294 \\
\hline
\end{tabular}
a. Predictors: (Constant), Size, Ml
b. Dependent Variable: ROA

Dari Tabel 4.8 nilai ( ) didapatkan 0,184 atau sebesar $18,4 \%$. Bisa dikatakan bahwa $18,4 \%$ varian ROA pada BUS tahun 2013-2017 disebabkan oleh kedua variabel terikat yaitu modal intelektual dan ukuran perusahaan sedangkan 0,816 atau $81,6 \%$ selebihnya diakibatkan oleh variabel lainnya.

\section{Pembahasan Hasil Penelitian}

Pengaruh Modal Intelektual Terhadap Profitabilitas

Hasil memperlihatkan modal intelektual 
memiliki nilai t 2,229 yaitu berpengaruh positif, level signifikans $0,031<0,05$ yaitu signifikan. Hal itu memperlihatkan bahwa intelektual mempunyai pengaruh pada profitabilitas (ROA).

Perusahaan yang bisa mengolah sumber daya yang dimiliki secara bagus maka mempunyai potensi yang bagus dibandingkan entitas lain. Sumber daya manusia yang terampil dan kompeten merupakan suatu keunggulan yang dimiliki perusahaan.

Perusahaan yang bisa mengolah sumber daya intelektual dengan baik, selanjutnya akan mampu meningkatkan kemampuan pegawai di perusahaan tersebut. Jika produktivitas dalam suatu perusahaan meningkat maka akan diikuti oleh meningkatnya profitabilitas. Selain itu apabila karyawan dalam suatu perusahaan mendapat gaji dan tunjangan yang tinggi maka kinerja karyawan tersebut akan bagus dan maksimal sehingga hal tersebut dapat meningkatkan profitabilitas perusahaan. Pendapat tersebut sesuai dengan penelitian Khasanah (2016), Ousama \& Fatima (2015), Faradina (2017), Dewanata (2016), dan Maisaroh (2015) menyatakan modal intelektual mempunyai pengaruh terhadap pofitabilitas.

Berbeda didapatkan oleh Kuryanto dan Syafruddin (2008), Firer dan William (2003) dengan hasil IC tidak mempunyai pengaruh terhadap profitabilitas. Mohiuddin et al., (2008) menemukan hasil yaitu modal intelektual tidak memiliki pengaruh terhadap profitabilitas.

\section{Pengaruh ukuran perusahaan terhadap profitabilitas}

Uji hipotesis memperlihatkan variabel ukuran perusahaan mempunyai pengaruh terhadap profitabilitas (ROA) BUS tingkat signifikan 0,010 $<0,05$. Mempengaruhi karena nilai dari koefisien regresi t 2,687. Memperlihatkan ukuran perusahaan memengaruhi profitabilitas (ROA).

Agus (2011:249) mengatakan perusahaan yang besar mempunyai kemudahan dalam mendapatkan modal dibandingkan dengan entitas yang masih kecil. dikarenakan adanya kelancaran tersebut perusahaan skala besar akan memiliki fleksibilitas yang tinggi. Perusahaan yang sudah besar lebih mampu mendapatkan investor dikarenakan adanya fleksibilitas dalam investasi yang bagus. Dikarenakan hal tersebut maka akan meningkatkan profitabilitas dalam perusahaan tersebut.
Perusahaan yang mempunyai aset yang banyak biasanya mendeskripsikan kemapanan dalam perusahaan, jika total aset semakin besar maka modal yang diinvestasikan dan ukuran perusahaan akan ikut besar, hal tersebut akan membuat uang dalam perusahaan akan berputar semakin banyak dan kemudian akan meningkatkan kinerja perusahaan tersebut. Hal itu sejalan dengan hasil penelitian oleh Rahmawati \& Tjahyadi (2017), Arini (2009), Dewi (2012), Akbar (2013), Hesti (2010), Tisna dan Agustami (2016) yang mengatakan ukuran perusahaan memiliki pengaruh pada profitabilitas perbankan syariah.

Berbeda Hidayat (2015), Setiawan (2009), Ali \& Ghazali (2018) ukuran perusahaan tidak memiliki pengaruh pada profitabilitas, dikarenakan ukuran entitas yang besar akan banyak beban untuk perusahaan.

\section{Kesimpulan}

Bedasarkan hasil pengujian dan analisis yang telah dilakukan mengenai pengaruh modal intelektual dan ukuran perusahaan terhadap profitabilitas bank umum syariah tahun 2013-2017, maka dapat disimpulkan sebagai berikut:

1) Modal intelektual berpengaruh terhadap profitabilitas Bank Umum Syariah

2) Ukuran perusahaan berpengaruh terhadap profitabilitas Bank Umum Syariah

3) Modal intelektual dan ukuran perusahaan secara bersama-sama berpengaruh terhadap profitabilitas Bank Umum Syariah

\section{Keterbatasan penelitian}

Penelitian ini mempunyai keterbatasan yang bisa dijadikan pertimbangan bagi peneliti selanjutnya sehingga dapat diperoleh hasil yang lebih baik dimasa yang akan datang. Berikut keterbatasan tersebut: Penelitian ini hanya menggunakan profitabilitas sebagai variabel dependen yang hanya diproksikan dengan ROA, sehingga tidak bisa melihat profitabilitas secara menyeluruh.

\section{Saran}

Berdasarkan hasil analisis, kesimpulan dan keterbatan yang didapatkan dalam penelitian ini, maka dapat dikemukakan saran-saran seperti berikut:

1) Untuk peneliti selanjutnya diharapkan 
dapat menambahkan beberapa variabel lainnya yang dapat mempengaruhi profitabilitas seperti Islamic Corporate Governance dan Islamicity Performance Index sehingga dapat diketahui variabel lainnya yang dapat mempengaruhi profitabilitas suatu perusahaan.

2) Untuk peneliti selanjutnya diharapkan dapat memperluas variabel profitabilitas dengan menambah rasio rentabilitas lain seperti ROE. Sehingga dapat diketahui pengaruh profitabilitas bank umum syariah dari sisi rasio rentabilitas secara menyeluruh.

\section{Daftar Pustaka}

Abidin, Sawarjuwono dan Kadir. 2003. Intellectual Capital Disclosure Commitment: Myth or Really?. Journal of Intellectual Capital. 13(1), 39-56.

Akbar, Dinnul Alfian. 2013. Analisis Pengaruh Ukuran Perusahaan, Kecukupan Modal, Kualitias Aktiva Produktif (KAP) dan Likuiditas Terhadap Kinerja Keuangan. Jurnal Ilmiah STIE MDP.3(1), 66-82.

Arifah, Sarah dan Medyawati, Henny. 2012. Analisis Pengaruh Elemen Intellectual Capital And Its Effect On Financial Performance Of Banks: Evidance From Saudi Arabia. ProcediaSocial and Behavioral Sciences. 164, 201-207.

Arini, Riska Irva. 2009. Analisis Pengaruh Ukuran Perusahaan, Kualitas Aktiva Produktif, Likuiditas dan Tingkat Suku Bunga Terhadap Kinerja Keuangan Bank Syariah Periode 2005-2008. Skripsi Dipublikasikan. Fakultas Ekonomi Universitas Diponegoro.

Ascarya. 2008. Akad dan Produk Bank Syariah. Jakarta: PT Raja Grafindo Persada.

Atif, Ali Syed dan Ghazali, Zahiruddin. 2018. Impact Of Firm Size On Profitability: A Comparativ Study Of Islamic Bank And Commercial Bank In Pakistan. Global Journal Of Management and Business Research: C Finance. 18(5), Version 1.0.

Bontis et al. 2000. Intellectual Capital dan Business Performance in Malaysia Industries. Journal of Intellectual Capital. 1(1), 85-100.

Dewanata et al.2016. The Effect Of Intellectual Capital and Islamicity Performance Index To The Performance Of Islamic Bank In
Indonesia 2010-

2014 Periods. JRMSI- Jurnal Riset Manajemen Sains Indonesia. 7(2), 259-278.

Dewi, Sartika. 2012. Analisis Pengaruh Ukuran Perusahaan, Kecukupan Modal, Kualitas Aktiva Produktif dan Likuiditas Terhadap Return On Assets (ROA) Periode 2006-2010. Skripsi Dipublikasikan. Makassar: Fakultas Ekonomi dan Bisnis Universitas Hasanuddin.

Fahmi, Irham. 2012. Analisis Laporan Keuangan. Bandung: Alfabeta.

Faradina, Lisca. 2017. Pengaruh Modal Intelektual terhadap Kinerja Keuangan Perbankan Syariah yang terdaftar di Bei Tahun 2013-2015. Jurnal Ilmiah Mahasiswa FEB Universitas Brawijaya. 5(2).

Firer, S., and S.M. Williams. 2003. "Intellectual capital and traditional measures of corporate performance". Journal of Intellectual Capital. 4(3), 348-360.

Ghozali, Imam. 2011. Aplikasi Analisis Multivariate Dengan Program IBM SPSS 19. Edisi 5. Semarang: Badan Penerbit Universitas Diponegoro.

Hesti, Diah Aristya. 2010. Analisis Pengaruh Ukuran Perusahaan, Kecukupan Modal, Kualitas Aktiva

Produktif (KAP) dan Likuiditas Terhadap Kinerja Keuangan (Studi Pada Bank Umum Syariah di Indonesia Periode 2005-2009). Skripsi. Semarang: Universitas Diponegoro.

Hidayat, Rahmad et al. 2015. Pengaruh Good Corporate Governance dan Ukuran Perusahaan Terhadap Kinerja Keuangan Perusahaan (Studi Empiris pada Perusahaan Perbankan yang Terdaftar di BEI 2010-2013). Jom FEKON. Vol 2(1), 1-15.

Jogiyanto, Hartono. 2013. Teori Portofolio dan Analisis Investasi. Yogyakarta: BPFE.

Karya, Supriyanto dan Rakhman, Abdullah. 2006. Analisis Kinerja Keuangan Bank Syariah Pada Periode 2000-2004. Keuangan dan Perbankan. 13(2), 209-221.

Kasmir. 2014. Analisis Laporan Keuangan. Jakarta: Raja Grafindo Persada

Khasanah, Anita Nur. 2016. Pengaruh Intelektual Capital Dan Islamicity 
Performance Index Terhadap Kinerja Keuangan Perbankan Syariah Di Indonesia. Jurnal Nominal. 5(1), 1-18. Kompas.com. (2018, 8 juli). SDM Belum Mumpuni, Perkembangan Industri Keuangan Syariah Terhambat. Diperoleh 5 Februari 2019, dari https://ekonomi.kompas.com.

Kuryanto, Benny dan Syafruddin, M. 2008. Pengaruh Modal Intelektual Terhadap Kinerja Keuangan Perusahaan. Proceeding SNA Xl.

Lestari, Dwi Santi et al. 2016. Pengaruh Intellectual Capital Terhadap Kinerja Keuangan Perbankan Syariah di Indonesia. Jurnal Ekonomi dan Keuangan. 20(3), 246-366.

Lestari, M.I., dan Sugiharto, T. 2007. Kinerja Bank Devisa dan Bank Non Devisa dan Faktorfaktor yang mempengaruhinya. PESAT. 2(1).

Maisaroh, Siti. Pengaruh Intellectual Capital dan Islamicity Performance Index Terhadap Profitability Perbankan Syariah Indonesia. Jurnal Fakultas Ekonomi UIN Malang. 2015.

Mohiuddin, Md et al. 2008. An Empirical Investigation of The Relationship Between Intellectual Capital, And Firms' Market Value And Financial Performance Bangladeshi Commercial Banks Contex. Journal of Business Administration. 34(1), 6993.

Muhammad. 2005. Manajemen Bank Syari'ah. Yogyakarta: UPP AMP YKPN.

Munawir. 2002. Analisis Informasi Keuangan. Edisi Pertama. Yogyakarta: Liberty.

Ousama, A.A and Fatima, A.H. 2015. Intellcetual Capital and Financial Performance of Islamic Banks. Internasional Journal of Learning and Intellectual Capital. 12(1).

Pulic, A. 1998. Measuring the performance of intellectual capital in knowledge economy. Retrieved from www.vaicon.net/start.htm. (accessed September 2019).

Rahmawati,_Imelda D dan Tjahyadi Bambang. 2017. Analisis Of ICG The Size Of Companies To Islamic Banking Financial Performance. Jurnal Atlantis Press. 125(1), 311-315.

Republika.co.id. (2018, 8 Desember). Penyebab Perkembangan Bank Syariah di Indonesia Lambat. Diperoleh 5 Februari 2019, dari https://republika.co.id

Rivai, Veithzal dan Sagala, Ella Jauvani. 2010. Manajemen Sumber Daya Manusia untuk Perusahaan. Jakarta: PT Raja Grafindo Persada. Riyanto, Bambang. 2008. Dasardasar Pembelanjaan Perusahaan. Yogyakarta: Penerbit GPFE.

Saint-Onge, Hubert.1996. Tacit Knowledge: The Key To The Dtrategic Aligment of Intellectual Capital. Strategic Leadership. February. Page 10.

Setiawan, Adi. 2009. Analisis Pengaruh Faktor Makro Ekonomi, Pangsa Pasar dan Karakteristik Bank Terhadap Profitabilitas Bank Syariah (Studi Pada Bank Syariah Periode 2005-2008). (Online). Jurnal Bisnis dan Manajemen 2 (3). (diakses 18 Februari 2019).

Siamat, Dahlan. 1996. Manajemen Bank Umum. Jakarta: Iner Media.

Suharso dan Retnoningsih, Ana. 2005. Kamus Besar Bahasa Indonesia Edisi Lux. Semarang: CV. Widya Karya.

Sutojo, Siswanto. 2004. Mengenali Arti Dan Penggunaan Neraca Perusahaan. Jakarta: Damar Mulia Taka

Sveiby, Karl Erik. 1998. Intellectual Capital: Thinking Ahead. Australian CPA. February,1821

Tisna, Andriani Gita dan Agustami, Silviana. 2016. Pengaruh Good Corporate Governance dan Ukuran Perusahaan terhadap Kinerja Keuangan perusahaan (Pada Perusahaan Perbankan Syariah yang Terdaftar di Bursa Efek Indonesia (BEI) Tahun 2016-2014). Jurnal Riset Akuntansi dan Keuangan. 4(2), 1035-1046.

Ulum, Ihyaul. 2007. "Pengaruh Intellectual Capital Terhadap Kinerja Keuangan Perusahaan Perbankan Di Indonesia”. Thesis. Universitas Diponegoro.

.2009. Intellectual Capital:Konsep dan Kajian Empiris. Graha Ilmu: Yogyakarta. 